\title{
En inspirerande satellit om hiv idag
}

Campbell, Alyson och Dirk Gindt (red.). 2018. Viral Dramaturgies: HIV and AIDS in Performance in the Twenty-First Century. Palgrave Macmillan. (4I7 sidor)

VIRAL Dramaturgies: HIV and AIDS in Performance in the TwentyFirst Century (2018) är en antologi med fokus på konstperformance och aktivistiska perspektiv på hiv och aids. Det är en satellitaktig samling nedslag i olika delar av världen, såsom Sydafrika, Kina, Papua Nya Guinea, Puerto Rico, Sverige, Australien, USA och England. Det är en antologi om teater, offentliga verk, workshops, arkitektur och muntligt berättande. Redaktörerna ramar in de sjutton bidragen, samlade under fem kapitel som jag översätter: I) Kvinnor, röster och erfarenheter, II) Generationer, minnen och temporalitet, III) Inter/nationella narrativ, IV) Artistiska och personliga reflektioner och interventioner, och V) Coda, eller slutscenen. En del av texterna är konstnärliga reflektioner, vissa essäistiska och saknar nästan helt referenser, medan andra är mer klassiskt akademiska. Här refereras förutom teaterteoretiker främst till det queerteoretiska fältet, med till exempel Judith Butler, Lee Edelman och Elizabeth Freeman, samt till kulturstudier med till exempel Susan Sontag, Douglas Crimp och Leo Bersani. Förståelsen av performance är inspirerad av Gilles Deleuzes och Felix Guattaris teoribildning som, förenklat sett, utgår från ett relationellt, komplext, icke-hierarkiskt och oändligt blivande. Redaktörerna framhåller per- 
formancens potential att dra in publiken i det gestaltade och därigenom göra den familjär med hiv.

Det finns flera lysande exempel på texter som är en njutning att läsa. Mest tillgängliga är texterna i det första kapitlet om kvinnors erfarenheter som har ett tydligt aktivistiskt anslag. Katharine Lows, Matilda Mudyavanhus och Shema Tariqs text handlar om betydelsen av självrepresentation bland kvinnor. I ett teaterprojekt i workshopform i Storbritannien med deltagare bestående av kvinnor, främst från Söder om Sahara, tas en gemensam tidslinje fram. Den visar att hivdiagnosen blir påtaglig vid vissa tillfällen, såsom vid graviditet. I andra fall tar annat $\mathrm{i}$ livet större utrymme än hiv, exempelvis en migrationsprocess. Low och medförfattare konstaterar att det behövs många olika sätt att uttrycka hivs förkroppsligande påverkan, hur kroppar och hiv möts rent konkret, eftersom det är enkelt att fastna i det rationella och intellektuella. Sarahleigh Castelyn påvisar konsekvenserna i det preventiva arbetet mot hiv genom spänningsfältet mellan modernism (det biomedicinska med effektiva mediciner) och traditionalism (där ursprungsbefolkningar ingår) med sårbara människor som hamnar i kläm.

I antologin framträder hiv med rätta som globalt och lokalt, kontextuellt och allmänt, kollektivt och individuellt. Hiv lyfts som erfarenhet, som berättelse, som politik och som nationell och internationell angelägenhet. Hiv lyfts även som ett fenomen som aldrig bara kan vara nutid (vilket kanske ingenting kan vara). PrEP - preexponeringsprofylax, det vill säga att ta hivmedicinen Truvada förebyggande för att inte få hiv vid kondomlöst sex - länkar nutiden till dåtidens krisår när inga effektiva mediciner fanns, men avslöjas också som en pågående epidemi, i och med att tillgången till mediciner är fortsatt ojämlik och att medikaliseringen av homosexualitet fortsätter genom Truvada. Titeln i Sky Gilberts text pekar ironiskt mot "post-aidseran". En känga ges även till den konservativa, normativa gaykulturen som strävar efter äktenskap och familjeliv som för att bevisa sin ofarlighet i relation till skuld- och skamkontot och idén om promiskuiteten efter I980-talet. Rädslan i dåtid och nutid förändras dock, där Marc Arthur menar att PrEP tar bort rädslan för att få hiv. Genom PrEP skapas därmed utrymme för begär 
och njutning, likt i en tid innan aids, med plats för det Ivan Bujan kallar för "raw sex", det vill säga sex utan kondom (andra STI:er såsom resistent gonorré nämns dock inte). I dessa texter om PrEP refereras det till forskaren Tim Deans (2015) medikalisering av homosexualitet och filosofen Paul B. Preciados begrepp (2013) pharmacopower, fritt översatt till medikaliseringsmakt. PrEP beskrivs ge både frihet och kontroll, där PrEP verkar både på kroppen (enligt Michel Foucault) och inom kroppen (medikalisering) och sexualiteten kontrolleras på molekylär nivå. I dessa texter försvinner andra målgrupper, till exempel kvinnor som är centrerade i andra kapitel, vilket visar hur målgruppsfokuserade även aktivister och forskare är.

I antologins sista kapitel intervjuar redaktörerna Sarah Schulman, en aidsaktivist, lärare och författare, om aktivism och populärkultur. Konversationen är intressant. Särskilt glädjande för en genusvetare är hur kvinnor inte bara beskrivs som vårdande allierade utan även som en viktig del av aidsaktivistgruppen ACT UP:s uppbyggnad, då den inspirerades av feministiska aktivister. Tydliggörandet att PrEP är anpassat efter en manlig befolkning, i linje med en föreställning om kvinnors sexuella passivitet, är också bra. En stor del av kritiken, såsom hur hiv och aids kapitaliseras genom både populärkultur och stora medicinbolag, är varken ny eller överraskande, men inte desto mindre viktig.

Även kriminaliseringen kring hiv, i form av informationskravet för personer med hiv att berätta om sin hivstatus innan sex, lyfts i intervjun och det är nödvändigt. Att Sverige nämns som det land som introducerade denna kriminalisering via Smittskyddslagen från I985, är också högst relevant i sammanhanget. Påståendet att informationskravet inte har förändrats i Sverige, "and to this day it hasn't really been dealt with" (392), stämmer däremot inte. Informationskravet i Sverige har vid välbehandlad hiv sedan 2015 kunnat hävas och sedan sommaren 2019 kan personer med välbehandlad hiv slippa ha kondom efter beslut av behandlande läkare (Folkhälsomyndigheten 2019; Smittskyddsläkarföreningen 2019). Det aktuella forskningsläget om överföring av hiv vid sex samt effekterna av hivmediciner gör att Smittskyddslagen tolkas annorlunda. Rättsväsendet har hörsammat detta och det juridiska, medicinska och 
sociala läget för personer som lever med hiv i Sverige har förändrats (även om detta är relativt okänt bland allmänheten och ännu inte fullt ut implementerat i vården). Det är viktigt att uppmärksamma de förändringar som sker, då svepande anekdoter om begränsande ramverk kan påverka personer som lever med hiv negativt.

Vidare finner jag att det saknas en kritik i inramningen till den Deleuzianska och affektiva ansatsen där hiv som fenomen, likt ett virus, genom performancegenren kan spridas till publiken som där också blir bekanta med hiv. Det individuella, kroppsliga och faktiska i form av hivmedicinernas biverkningar och de sociala konsekvenserna av att leva med hiv, menar jag inte är gemensamma och delade upplevelser. Det tillhör vissa kroppar, vi som har en positiv hivstatus, och här skrivs viruset in i vårt DNA och i våra sociala situationer. Det transformerar oss. Givetvis sker det i relation till samhället, men samhället transformeras inte såsom vi gör. Att Jacqueline Kauli nämner att teaterns transformativa potential riskerar att misslyckas genom att återupprepa historiska ojämlika mönster är en lättnad.

Det essäistiska anslaget blir ibland ett hinder för ökad vetenskaplighet. I avsnittet om Torka aldrig tårar, av Dirk Gindt, saknar jag referenser till tidigare forskning om representationer av och berättelser om hiv (t.ex. Ljung 20or; Ljungcrantz 20I7), samt kritiska inlägg om själva teveserien (Edenheim 20I2; Trenter 20I8). Samtidigt är det ofta de aktivistiska, essäistiska bidragen som lyser starkast. De befinner sig nära hiv och personer med hiv, både i då- och nutid. De grupper som inte lika tydligt representeras i antologin är exempelvis transpersoner, personer med funktionsnedsättningar, samt erfarenheter baserade i Mellanöstern eller Östeuropa. Detta beskrivs av redaktörerna i introduktionen. Drogbrukare samt barn och unga är andra erfarenheter som inte täcks av antologin. Kanske visar detta vilka som har varit och är hivaktivister och vilka det skapas performance om och med? Det är dock inte rimligt att kräva full representation av alla heterogena grupper som berörts och berörs av hiv i en enda antologi.

I slutet av boken konstaterar Schulman angeläget att vi behöver finna nya och andra berättelser om hiv än de dominerande och ständigt repe- 
terade troperna. Jag håller med och menar att antologins styrka är just att den samlar både det välbekanta och det nya. Sammantaget är Viral Dramaturgies en imponerande antologi med både bredd och djup. Den är verkligen en satellit som söker av nutidsläget genom vissa nedslag i världen, performancekulturen och i olika målgrupper. Hiv är ett fenomen som är under konstant förändring och som samtidigt har seglivade historiska trådar och mönster. Just på grund av hivs föränderliga förutsättningar och antologins fängslande samling texter, önskar jag att satelliten kan fortsätta att göra nedslag och att en uppföljare av Viral Dramaturgies blir till.

\section{DESIREÉ LJUNGCRANTZ}

\section{REFERENSER}

Edenheim, Sara. 201 2. "Gardell gråter bara för männen." Dagens Nyheter, 2 I november. https://www.dn.se/kultur-noje/kulturdebatt/gardell-grater-bara-for-mannen/.

Dean, Tim. 2015. "Mediated Intimacies: Raw Sex, Truvada, and the Biopolitics of Chemoprophylaxis." Sexualities I 8:I-2:224-46. https://doi. org/I0.1177\% ${ }_{2} \mathrm{~F}_{13} 634607$ I5569137

Folkhälsomyndigheten. 2org. "Smittsamhet vid behandlad hivinfektion." https://www.folkhalsomyndigheten.se/publicerat-material/publikationsarkiv/s/ smittsamhet-vid-behandlad-hivinfektion/.

Ljung, Anna. 200I. "Bortom oskuldens tid: En etnologisk studie av moral, trygghet och otrygghet i skuggan av hiv." Avhandling, Uppsala universitet.

Ljungcrantz, Desireé. 2017. Skrubbsår: Berättelser om hur hiv föreställs och erfars $i$ samtida Sverige. Göteborg: Makadam.

Preciado, Paul (Beatriz). 2013. Testo Junkie: Sex, Drugs, and Biopolitics in the Pharmacopornographic Era. New York: Feminist Press at the City University of New York.

Smittskyddsläkarföreningen. 2019. "Hiv: Person med välinställd behandling, patientinformation." https://slf.se/smittskyddslakarforeningen/app/uploads/2org/o7/hivpat-med-valinstalld-behandling-r90703-korrekt-titel.pdf.

Smittskyddslag. SFS 2004:I68.

Trenter, Cecilia. 2019. "Voices of AIDS: The HIV Virus and the Shaping of a Cultural Memory." I A Visual History of HIV/AIDS: Exploring the Face of AIDS Film Archive, redaktörer Elisabet Björklund och Mariah Larsson, 44-56. Abingdon: Routledge. 